\title{
Musil's Idea of Poetic Mastership and Responsibility Or: Törless as his First Attempt to Become a Serious Writer
}

\author{
Kathrin H. Rosenfield ${ }^{1}$
}

\begin{abstract}
Musil uses the word Dichter, poet, as a dignified title reserved for artists of great achievement (different from Schriftsteller, writer). His use of the word emphasizes the importance of the specifically poetic qualities of literature (and of the poetic sensibility of criticism,) not as an idle objection to the contemporary merging of literary works with either pure sensation and feeling, or with other forms of discourse. Focusing on Törless, as well as on Musil's notebooks and essays, this article shows how Musil understands the relationship between rational thinking and the latent ideas and thoughts that emerge within the poetic dimension (the 'other state of mind" or 'other condition.') This approach illuminates Musil's conception of "precision and soul" - the interlocking of sensitive perceptiveness and intellectual rigor - as a necessary pre-condition for valuable literature and valuable life.
\end{abstract}

Key-Words: Musil, poetic mastership, Törless, essays, notebooks.

Resumo: Musil costuma usar o termo Dichter, poeta, como um título de maior dignidade para grandes mestres (opondo esse termo à palavra mais contemporânea Schriftsteller, escritor). Esse uso sustenta a ideia das qualidades especificamente poéticas da literatura (e da sensibilidade poética da crítica), reagindo contra as tendências contemporâneas de fundir os discursos literários ou com a pura sensação, ou com outras formas discursivas. Partindo de Törless e de alguns ensaios de Musil, esse artigo mostra como Musil entende a relação entre o pensamento racional e as ideias latentes que emergem da dimensão poética (do "outro estado da mente" ou da "outra condição"). A abordagem ilumina a concepção musiliana de "precisão e alma", isto é, o entrelaçamento entre percepção sensitiva e rigor intelectual como uma condição para a busca de valores literários e existenciais.

Palavras-Chave: Musil, maestria poética, Törless, ensaios, diários.

\footnotetext{
${ }^{1}$ Ph.D. Professor at Federal University of do Rio Grande do Sul. This research is sponsored by CNPq. Email address: kathrinhr@gmail.com. This article is a partial result of a research in the framework of a "Estágio Pós-doutoral" financed by CAPES.
} 


\section{Mastership as a Balance of Intellectual Precision and Poetic Sensibility}

In 1927, in his obituary for Rilke, Musil not only expressed his grief for the loss of the "greatest lyric poet [...] since the Middle Ages", but also used Rilke's death as an opportunity to reflect on poetry and poetic mastership. He argued that it was necessary to "rectify the concept of poetic importance as such, inasmuch as it has become uncertain" in contemporary culture and cultural institutions (P 1229) ${ }^{2}$. What, he asked, did Rilke's career say or suggest about the poet's specific task in the "firm and fixed world, [which should be able to deal with] the feelings which represent what remains mobile, flexible and changeable" (Id.) in the universe of positive knowledge and rational practices?

Some two decades earlier, when Musil considered himself a scientist rather than a poet, he was not sure if or how this poet's task could become his own. He started writing his first novel around 1902, after a few uncertain literary attempts during the years $1899-1901^{3}$, when he was still struggling to find original modes of reshaping the literary tropes of his recent literary acquaintances. His early writings share with the decadents and aesthetes of his time the rejection of a reality that seemed sterile and mechanical, ugly and repulsive to more passionate and sophisticated individuals. However, Musil quickly became critical of his own decadentism, and the aestheticism in his first novel can be presented as an important step moving beyond it.

Although this view may be far from unanimous, ${ }^{4}$ the present essay argues that Musil's conception of the poet's role was already beginning to constellate itself in his

\footnotetext{
${ }^{2}$ Cf. Musil's essays and smaller prose writings (MusiL 1978), quoted with the abbreviation (P followed by the page number).

${ }^{3}$ As a member of the Ästhetische Gemeinde in Brünn, Musil tried out the artistic fashions which show the impact of local writers like Richard Schaukal, Franz Schamann and Karl Hans Strobl, as well as his reading of Nietzsche, Emerson and Maeterlinck; in his diaries, he refers to himself as Monsieur le vivisecteur. About these influences in the early work of Musil cf. MULOT 1977: 74s., about the decadent dissecting of feelings and the aestheticizing yearning for expression; Mulot considers that Musil was already overcoming these tendencies by 1902 (126).

${ }^{4}$ The idea of Musil's early progress from decadent aestheticism to moral considerations is shared by Mulot, who presents a thorough analysis of Musil's relations with literature and art of the turn of the century (cf. in particular, MULOT 1977: 110-126). Many other authors, however, do not agree: Stefan Howald's close reading of Törless rejects the idea that Musil's early work contains a "precocious staging of the tension between the aesthetic and the ethical," which Mulot considers to be an important artistic experiment (HOWALD 1984: 21). Howald vehemently objects that he sees, instead of an "overcoming" of the position of the aesthete "an almost wild flowering of aestheticism (naturwüchsig aufbrechen),
} 
Rosenfield, K. H - Musil's Idea of Poetic Mastership

first and quite spontaneous poetic attempt, Törless ${ }^{5}$, and that the character Törless exorcized the decadent posturing of the aesthete, which Musil was beginning to recognize as a menace to his artistic development.

This is another way of saying that there is a continuity in Musil's oeuvre, a continuous growth of density and mastership which links his first novel, novellas, and plays to his masterwork, The Man Without Qualities. The author himself certainly thought so and complained bitterly about having been underestimated as a Dichter during the decades before the publication of the first volume of his great novel. In March 1931, when The Man Without Qualities received the praise of being "the most important European novel," ${ }^{, 6}$ he urged his friend Johannes von Allesch to write a longpromised critique and show "that this latest novel is nothing but the broadest development of the previous works" (MusIL, Briefe, I: 327).

The idea of a progressive interweaving of aesthetic and ethical concerns is not altogether obvious in Törless. In the first place, this is because the plot - involving adolescence and sexuality, homosexual and sadistic experiences, as well as the psychological and physical abuse of a student by three of his inmates in a military boarding school - was sensational in the early twentieth century and still seems to have the power to distract attention from the other issues in the novel. This surface plot

inasmuch as the material of experience which is artistically elaborated rebels against the higher [ethical] perspective." (21) Howald's position has been shared by many major Musil scholars, like Matthias Luserke, who suggests that there remains a certain cynical affinity between the author and the character Törless at the end of the novel, when Törless turns away with indifference from the ugly cruelties he has been accomplice to. Luserke asks whether the metaphor of the accomplished cycle of development which inspires "a wordless, overwhelming feeling excusing everything that had happened" should be understood as "cynicism of the author, or as irony, or simply as Kitsch? This can hardly be read as a biting commentary of the young Musil against the social relations of his time". Luserke considers that the novel prolongs "the long series of efforts trying to lend discourse to desire which started in the early history of bourgeois society, with Goethe's Werther." (LUSERKE 1995: 34). Peter Henninger also investigates the "ambiguities" and the "cunning" of Musil's texts and quotes Luserke in order to point out a continuity between Törless and Tonka which show the male heroes' "social clichés [...] [and] [...] their use of the women for their own interests" (HENNINGER 2007: 233); the author suggests a parallel between the literary characters and the author's attitudes in real life. - In other words, many critics still share Howald's sociopolitical and moral verdict that Musil's "aestheticism is not a mere form of thought, but also a form of behavior, as can be shown in Musil's relationship with Herma, who became for him nothing else but a sexual object and an object of pity and educational interest." (HowALD 1984: 22)

${ }^{5}$ All references with the abbreviation $\mathrm{T}$ followed by the page number refer to The Confusions of Young Törless in the German original Die Verwirrungen des Zögling's Törless, included in Musil's essays and smaller prose writings (MUSIL 1978).

${ }^{6}$ Musil's letter to von Allesch referrs non-specifically to different critiques in reviews: "It is said, for example, [that the MwQ is] among the European novels the most important; or: No other German novel achieves this utmost level" (GW I: 327). 
seems to raise such a wealth of realistic problems - psychological and educational ${ }^{7}$, social, political and moral - that it is no wonder literary critique has discussed them from the most varied angles and methodologies. Only few authors have concentrated on the aesthetic-and-ethical dimension. One of the earliest was Sibylle MuLot, who showed the author's intention of overcoming the aesthetic stereotypes of his environment and of the decadent aestheticism of the Fin de Sciècle (cf. Mulot 1977: 74-127). Her view has been contested by critics who perceive Törless in a more negative way. Some of these have interpreted the novel as the emblematic "evasions of the aesthete" - both Törless and Musil being viewed as displaying an a-moral attitude in David TURNER's approach (1974), which accuses Musil of complicity with the apolitical gesture and the accommodating retreat to the private sphere typical of the Naziregime. Stefan HowaLD (1984) is more moderate but considers that Törless' often cruel aestheticism is, nevertheless, the underlying model for Musil's own behavior in real life $^{8}$. The reading of Törless as a portrait of bourgeois mentality has been widespread from the 1970s onwards, and Törless has been viewed since then as the very image of the disoriented intellectual (cf. BAUR 1973; MATTENKLOTT 1973). The idea that Törless is somehow Musil's alter ego, and that Musil submitted passively to the ruling norms of morality and to the repressive authoritarianism of his time - Horkheimer's and Adorno's authoritarian personality - has become one of the critical topoi of literary critique in the past decades (cf. BERGHAHN 1963; GOLDSCHNIGG 1981; HOWALD 1984; 30; POTT 1984; LuSERKE 1995, HENNINGER 2007).

However important the investigations of the social, political, economic and ideological context have been for the understanding of the novel, it should not be forgotten that young Törless is not an adult intellectual, and that the choice of an unstable adolescent can and should point into various possible directions. This is why we start with a critical reevaluation of Törles' emotional attitude. This has been considered as almost exclusively passive, as in Wolfgang FRIER's lengthy analysis of the Language of Emotionality in Musil's Törless (1976), which is the basis for many of later interpretations. We will show that the hero's passive egotism, which draws on the

\footnotetext{
${ }^{7}$ The educational and social aspect fascinated Musil's contemporaries and becomes particularly clear in Kisch's Obituary, cf. TB II, 204. Musil perceived it as a misreading and an insult to the artistic nature of his novel; cf. P, 947.

8 "Törless' speech becomes an auctorial reflection; he seems quite obviously to stand for a medium of recognition which goes beyond the fictional character and which is posited as a principle for Musil's entire oeuvre." (HowALD 1984: 22; 25 s., and 73)
} 
Rosenfield, K. H - Musil's Idea of Poetic Mastership

philosophical and literary stereotypes of impressionism, is best seen as an active refusal to develop other alternatives and attitudes (artistic or scientific) which the narrator points out as more desirable than Törless' choices. Musil's narrative technique discretely sketches in a remote horizon of moral and artistic values which the confused egotism of the adolescent does not bother to conceive.

The focus of the present article joins from a different angle the rarer approaches of the aesthetic aspects of the novel - views like that of KNÜPFERMANN, who takes Törless to be the "model for Musil's creative process, "which bears resemblance to [Schlegel's] progressive transcendental poetics" (KNÜPFERMANN 1986: 94), or of Gilbert REIS (1983), who sees in Törless the expression of Musil's own definition of the writer's true objective, i. e., the investigation of some undefined and inexpressible experience beyond the positive rational domain. Aldo VENTURELLI, in an inspiring chapter on Törless (cf. VentURELLI 1988: 138s.), picks up Marie-Louise Roth's ideas about the impact of Gestalt theory on Musil's conception of creative configurations as mediating between the merely abstract, rational concepts and the supposedly irrational (immediate) feelings and intuitions. This connection, so important for the understanding of Musil's theoretical and essayistic work, is often lacking in the appreciation of literary criticism ${ }^{9}$.

In recent years, a few essays have presented Törless from diametrically opposed perspectives. Stanley CORNGOLD (1992) investigates the reader's response to the ethical and aesthetic aspects of Musil's work; he wonders how Musil succeeds in stimulating positive responses although his plots contain potentially offensive materials. Jacqueline MAGNOU ${ }^{10}$ (1995) comes back to the topos of the "bourgeois intellectual", reluctant to participate in the "active transformation" of society, and compares Törless to the selfindulgent "hypertrophic Ego" in Schnitzler's work, whose individualism and apolitical attitudes act out the Hegelian unhappy consciousness. A generally positive view of Törless' formation adventure is given by Allen THIHER in 2009. His essay concentrates on the "cathartic experience" that allows the hero Törless to come to an "emotional, not yet intellectual, recognition of what the recent [bullying] experience meant" (THIHER, 2009: 68). Patrizia MCBRIDE's book The Void of Ethics (2006) focuses on the limits of

\footnotetext{
${ }^{9}$ A decisive contribution is Silvia BonACCHI's Die Gestalt der Dichtung. Der Einfluss der Gestalttheorie auf das Werk Robert Musils (1998).

${ }^{10}$ MaGnou (1995: 172-181) basically synthecizes the views of cultural criticism and Ideologiekritik (BAUR, MATTENKLOTT, and others).
} 
Rosenfield, K. H - Musil's Idea of Poetic Mastership

language: Törless' confusions are linked to the investigation of another reality - a reality more intense and vivid than everyday experience or rational thought. His failure to express it is the source of his confusions which have to be overcome by acknowledging the gap. MCBRIDE points out, however, that Törless' solution to "renounce the investigation of the unfathomable "other" realm"" is not Musil's, who "productively draws on his training in the natural sciences do redefine literature as an ambitious intellectual enterprise" (Id.: 52) ${ }^{11}$.

Our essay proposes to approach the ethical dimension of Musil's writing (and, ultimately, its political implications) from the perspective of the author's struggle for poetic excellence. There is a marked difference between the aesthetic proclivities of the adolescent Törless - similar to the decadent, authoritarian, proto-fascist mindset of his time - and the view taken by the narrator and the author. The text of the novel signals that there are different outcomes and possibilities which might result from a refined aesthetic sensibility like Törless'. Pursuing the narrator's hints, this essay will follow up Renate Schröder-Werle's descriptive approach (SCHRÖDER-WERLE 2001), which reconstructs the author's views of the aesthete as opposed to the serious writer. We will add a few of Musil's annotations taken from the notebooks (Musil's remarks about his friend Allesch, so far unmentioned by literary critique) and from his essays. Our last step will lead from Törless to the author, in search of a better contextualization of Musil's own individualistic, a-political attitudes. Instead of interpreting them as an appeasing accommodation (cf. TURNER 1974: 41), we will attempt to understand them rather as a move towards Musil's mature conception of serious writing and poetic responsibility.

Our perspective will advance this idea in three steps:

a) We will reevaluate the novel itself, with a few observations about what has been missed by interpreters who focused on Törless' passive and amoral, sensuous and mostly private tendencies; this will be done by pointing out a few passages in which Musil suggests that Törless' experiences might lead to thoughts, attitudes and actions which he does not pursue - neither in the narrative present, nor in the future, which the author anticipates at decisive moments in the novel.

\footnotetext{
${ }^{11}$ Cf. particularly McBride 2006, 46-52, about Musil's handling of the inexpressible, his Romantic tropes, and the anthropological views of the pre-linguistic and pre-conceptual experiences.
} 
b) We will put these passages into a biographical context, using Musil's remarks in his notebooks about aesthetes, their choices and attitudes, which annoy him, already in 1905 , before the publication of the novel.

c) We will suggest a wider perspective which puts Musil's apolitical stance in the specific context of his later trajectory in the 1930s, in which his refusal to put literature in the service of political programs can be seen as a morally and politically responsible choice. Musil's attitudes, often qualified as prone to the passive appeasement of authoritarian practices, become clearer in the years when he himself is threatened, on the one hand, by fascist repression, on the other by ideological harassment and defamation from the left. (Kisch, with whom he had shared ideas of political activism after the first World War, vilified Musil's image quite unjustly after the Conference for the Support of Culture in Paris in 1935, when Musil courageously defended the independent and individualistic freedom of the artist against the control and instrumentalization of art in the name of a centralized State).

Before entering into these questions, however, a quick outline of the double plot of The Confusions of Young Törless.

\section{Törless as the Embryo of Musil's Idea of the Poetic-and- Intellectual Balance}

Törless has two plots. The first plot is the action set at the military boarding school. It consists of Törless' encounter and brief friendship with a young prince and, after the prince's sudden departure, Törless' relationship with two older students, Reiting and Beineberg. The second plot has to do with Törless' intimate adventures with new feelings and thoughts. In this plot, the entanglements of unusual inner and outer experiences lead to confusions and bewilderment and remain unsolved in Törless' immature mind. It is clear from Musil's insistent remarks in letters and essayistic fragments (cf. SCHRÖDER-WERLE 2001: 38-42) that the author considered the second, or inner, plot as the more important of the two. The educational problems suggested in the first plot, which fascinated his contemporary readers, bored him; and the socio-political implications of the first plot gained his interest only in the 1930s, when he observed in 
dismay that certain practices of Fascism and Stalinism proved to follow quite literally the Reiting-Beineberg model (Ib.: $77 \mathrm{~s}$ ).

The most succinct way of describing the first plot is to say that it is built around a few typical and rather banal incidents of adolescence: the spring awakening of puberty, conversations about emotional and intellectual doubts, rivalry between classmates, efforts to define their respective personalities within the (poor) elements provided by the environment and the conventional discourses of the family and the school. These events are bathed in an atmosphere of general boredom typical of adolescence, a tedium which the more active boys try to break by a grim bullying experience. The bullying is initiated by Törless' two friends, who are more interested in intrigue, influence and power than in aesthetic subtleties. Reiting can be seen as representing Nietzsche's will to power in its simplest and most tyrannical form, while Beineberg represents the contemporary intellectual of the mystifying type (Klages, Maeterlinck, Keyserling ${ }^{12}$ ). They take the lead in a sadistic experiment that mirrors, as a farce, the educational ideals of their school and cultural environment. Reiting surprises his colleague Basini in the act of stealing money from his schoolmates' lockers and subjects him to humiliations and punishments which are supposed to better and redeem him. These quickly lead to sadistic excesses, psychological and physical abuse, and homosexual exploitation. There is no doubt that Musil anticipates glimpses of the protofascist mindset, and that his first novel can be read as a case-study of Freud's polymorphic-and-perverse plasticity of childhood sexuality ${ }^{13}$. Nevertheless, Törless' central crisis is both broader and deeper than the sado-masochistic and homosexual plot going on in the red chamber, a theatrical space in the attic of the school, where the three friends force Basini to submit to their "educational" tortures - as if they were repeating, in a gruesome farce, the educational rhetoric of their environment ${ }^{14}$. The bullying episode is part and symptom of a larger crisis, one that is educational, social and political as well as individual. The individual element of the crisis starts long before Törless befriends the two older boys, who already seem to be rehearsing certain

\footnotetext{
${ }^{12}$ Cf. FRIER 1976: 249 - 285, about the philosophical and literary versions of impressionism.

${ }^{13}$ Many critics have noticed this. Musil himself mentions the political implications which were not clear to him when he wrote the novel, but became surprisingly obvious in 1936 and 1937; cf. TB I 834 and 914. As to psychoanalysis, the author is more reluctant.

${ }^{14}$ Cf. Musil 1978, P 1206 ss., / PS 70 ss., (essay "Literat und Literatur" (September 1931), on the hybrid position (Doppelprofil) of the serious writer who uses the social rhetoric of his time in an effort to overcome, with an aesthetic achievement, this historically pre-determined scenario.
} 
characteristic types of solutions to a problem which is still vague, warm and flexible in Törless' mind. While Törless is still struggling with the discovery that moral principles are frighteningly shaky, Reiting and Beineberg imitate Macchiavelli's Prince: they try to establish order through hierarchies based on intellectual and physical force, and they practice the cunning of intrigue and the tricks of intellectual mystification.

The introductory narrative offers a lengthy portrait of Törless' inner void, his moods, feelings, and thoughts, his waiting for suggestions from the outside world on which to project and graft his ideas and fantasies. When the action starts, Törless' turmoil is still an uneasy searching for new aims and compensations which might fill the emptiness left by the loss of the sheltering environment of childhood and the proximity of his mother and his home, a void that his new educational and supposedly cultural environment proves unable to fill. It is precisely for this mobility of imagination and thought that Törless is singled out by the older boys at the beginning of the novel. His feelings of homesickness and abandonment, his vague, overwhelming nostalgia, and the terrors of emptiness set in motion a precious moment of awakening for him, before he starts to withdraw from his virtually precious, but uncanny, discoveries.

Törless' second plot - which Musil considered to be the main plot - takes place in the inner theatre of Törless' feelings of abandonment and isolation. His sensuous and erotic experiences graft themselves upon literally anything in the surroundings: from the sight of working women in the village to Beineberg's bodily movements, from the sight of the empty blue sky to mathematical problems. Musil follows meticulously the constant shifting of the sensuous and sexual perceptions towards intellectual ruminations. In Törless' mind the scientific and philosophical concepts tend to become metaphors of the obscure, sensuous, almost erotic, feeling: both enhance the enigma of a gap or void in space; the mathematical notion of incommensurability between real and imaginary numbers becomes just another image of the cracking and crumbling of conventional orders. This process is put in motion again by the shock of Basini's theft: for the first time, Törless feels the fragility of the bourgeois morality (Standesethik) that he was used to and he quickly perceives that the educational "improvement" acted out by his friends is a farce of conventional morality. However, Törless' lively and inquisitive mind constantly slips from one level of experience to another, producing countless analogies and similes, which create an aura of mystery around persons, things, and lived experiences: in other words, he chooses not to think through the difference 
between the fluid, ambiguous order of feelings and imagination, on the one hand, the firm notions of experience and concepts (moral or scientific), on the other. Though he opposes Beineberg's more simplistic tendencies towards mystification, Törless nevertheless equally seeks to preserve the almost mythical charm, the shudder of delight and horror, of a world capable of inspiring passionate sensations and feelings, and a promise of mystical revelations hovering beyond and above the immediate experience. Törless combines this insistence on the sensuous thrill of things and experiences with a haughty and almost arrogant, defensiveness. Always in search of delight and sensitive excitement, he uses intellectual distance to ward off the threat lurking in strong experiences. He assumes the position of a neutral observer who pretends not to be involved in what he sees. Although he often acts as an eager accomplice of his more obviously active and brutal friends, he tries to convince himself and others that he is able to remain outside of his experiences, untouched by what he lives through.

Reiting's and Beineberg's alliance with the younger Törless maps out the two crucial moments of adolescence: on the one hand, the awakening of (and to) something unknown, the opening of an uncanny-and-promising horizon, the immense possibilities and risks of this frightening and enchanting indeterminacy; on the other, the urge to escape from a vagueness that is both magical and hellish. The older boys have already yielded to the urge to define and reduced their experience to clearly outlined role-plays; they fall back again and again on a small number of rhetorical and behavioral tricks which become characteristic of their identities. Musil's diaries and essays are full of sharp analyses of the habits of formulaic expression, the mental and psychological economies offered by "packaged bundles" of ready-made attitudes - intellectual and emotional ${ }^{15}$. Retrospectively, we might see the four young boys (as Volker Schlöndorff did) as examples of a proto-fascist mindset: Reiting is the master of intrigue, the wouldbe tyrant, Nietzschean Übermensch or Machiavellian Prince, prying into his colleagues' secrets and using them strategically for his ever-shifting alliances, fuelled by threat and seduction, blackmail and cruelty. Beineberg is the dictator's athletic, elitist counterpart, sometimes his willing assistant, sometimes his rival, finding refuge in the vague promises of old sacred practices with the ingredients of sacrifice and chastisement. Beineberg builds his sense of superiority on a makeshift foundation of mysticism and

\footnotetext{
${ }^{15}$ Cf. P 1220/ PS 84s: conceptual formulae, in particular, cool down the vividness of impressions, and anaesthetize lively experience; such practical simplifications permit summation, but they also fall short of what is decisive for relevant (ethic, intellectual and emotional) experience.
} 
Rosenfield, K. H - Musil's Idea of Poetic Mastership

esoteric secrets, pieced together with the debris of his father's collection of symbols and cultures brought back from his military assignment in India.

Törless' wealth of imagination and subtlety of intellect give him distinction in the minds of the older boys and make him a welcome ally in their struggles with boredom and educational poverty (he is seen as the Generalstabsoffizier). Basini, the untalented and effeminate colleague, is the ideal victim; he is silly enough to advertize his (imaginary) cavalier adventures with the local prostitute, and he maneuvers constantly towards positions of great fragility. It is because he lives beyond his means that he falls into the hands of Reiting, who catches him stealing from the other boys' lockers and reduces him to the role of the scapegoat for the older boys' frustrations and the slave of their as yet unconfessed desires. Basini's moral flaw becomes the pretext for subjecting him to their ambiguous cruelties, while his homosexual tendencies will soon be found out and used as an escape valve for their deeply disturbing mixture of cruelty and sexual desire.

The four adolescents are both individual characters and social types. They already show Musil's sharp memory for the specific rhetorical differences between the formulaic diction of individuals and groups ${ }^{16}$. To a certain degree, the four young men are the predictable results of cultural conventions reshaped and petrified by a rigid system of education: Reiting the dictator, Beineberg the mystifying elitist, Basini the mindless and submissive follower; Törless, the talented and sensitive young man. Törless stands on the brink of missing his chance to face the aesthetic-and-ethical challenge which might transform him into a remarkable person or artist and will later become the type of the versatile aesthete, the detached connaisseur who withdraws from his feelings and watches them with a certain mechanical indifference, feigning to be a mere observer of a situation which cannot touch or move him $^{17}$.

\footnotetext{
${ }^{16}$ Cf. P 1205 s. / PS 72 s. ("Literati... essay”): Musil explains that serious literature (schöne Literatur) and great poets are rich in examples and precise quotations of the rhetoric and particular diction of their characters - as opposed to the vague clichés of journalism and consumer literature.

${ }^{17}$ Cf. P 1220 / PS 85 ("Literati... essay"): about ready-made formulae that function as protective shields.
} 


\section{Musil's Analysis of Possible Alternatives for Törless Trajectory}

In all the writing about the relationship between power and sexuality in this book, little attention has been paid to the implicitly critical attitude that Musil's narrator takes towards Törless' aesthetic finesse. There are quite a few passages in which the narrative technique makes it clear that Törless' passive indulgence is a path that he has chosen and a repudiation of other possible paths along which his artistic and moral development might have progressed. Musil and his narrator see Törless as a boy who is not merely sensitive but "hypersensitive"18. his excessive refinement makes him more interested in the "sound-color" (Klangfarbe, Törless: P 19) of another person than in the person as such. Musil sees this tendency as a reactive behavior, a refusal to integrate physical and emotional experiences with rational thought. Musil dislikes the aesthete's artificial and often perverse efforts to heighten the delight conveyed by things and to intensify feelings and sensations which tend to lose their charm over time, becoming trivial routine (cf. Mulot 1077: 74 s.; HowALD 1984: 18-22). He believes that the aesthete's lack of sober truthfulness and attentive confrontation with the inner pattern of feelings and thoughts ultimately betrays both feelings and intellect, leading to the mystifications and myth-making ${ }^{19}$ which Musil criticized in the culture of the early $20^{\text {th }}$ century. Let us show this with an example.

In the beginning of the novel, Törless' sensitivity can be perceived as a spontaneous gift of a talented and probably artistically gifted young man. However, Musil progressively underlines Törless' artificial and cerebral effort to remain within such feelings, even to intensify and heighten them, instead of integrating them creatively with his intellectual sharpness - which would offer an artistic solution to his confusions. The mathematical enigma of the imaginary numbers is one such missed

\footnotetext{
${ }^{18}$ Musil starts early to work against his own hyper-sensitivity: cf. below, his self-critical remarks in the notebooks about his youthful urge to remain in the sphere of inspiring music and erotic passion.

${ }^{19}$ Cf. also FRIER 1976: 308-10, about the 'mythification' (Mythisierung) and the mystification in the mental habits of Musil's contemporaries (and his fictional characters). They tend to treat the effects of certain actions or occurrences as embodiments of obscure forces instead of observing them more soberly and describing their precise and sometimes quite banal functioning; abstract notions are thus transformed into mythical and almost magical agents (soul, spirit, void, otherness). Frier points out the emotional and ideological benefits of this mechanism (the enchantments of fairy tales and the manipulations of propaganda). Musil's idea of a better equilibrium precision and soul tries to overcome this then-current abuse.
} 
opportunity. Törless' musing about the gap between the two incommensurable orders (real numbers and imaginary numbers do not respond to the same logical order) is closely linked to his intimate yearning for the mysterious something, an unknown "beyond" which haunts him: he intensely experiences the feeling of a void in the blue sky which seems to suck him towards another dimension; he remembers a childhood experience - the ambiguous shudder of horror and delight conveyed by the sudden awareness of solitude and abandonment; or he remains with his eyes fixed on the interesting elegance of Beineberg's hands which delight and disgust him - all these 'mysteries' (complex or trivial) are filled up and over-determined with sensuous aesthetic images which enter, like the tiny drops of water in clouds, in ever-changing connections and constellations ${ }^{20}$. Törless' mind repeats compulsively the vague, associative connections of imprecise analogies. Refusing to work through the difficulties of serious philosophical or scientific thought, he remains in the realm of gliding resemblances, which allows him to muse about the mathematical problem in the same eroticized way in which he riddles over Basini's theft or contemplates Beineberg's hands. He chooses to see the acrobatic distortions of things (Verzerrungen und Verrenkungen, T: 19) and the flaws of abstract orders, guided by his senses which are reluctant to give up their habitual preferences, often linked to his childhood reminiscences, tastes, conventions and erotic desires.

Let us have a look at his mathematical problem. The fact that he proves unable to pursue an exciting mathematical problem more seriously is equally linked to two essentially aesthetic factors. The first is the humble appearance of his Mathematics professor. His dirty socks and tasteless cravat are aesthetically repulsive to Törless, and the professor's unfortunate observation that the higher mathematical truths have to be believed before they can be understood triggers the agnostic sensibility that Törless' has inherited from his parents' enlightenment Bürgertum. More important, though, is the fact that Törless also stumbles over a second hurdle, which might have opened a new path for him, had he taken it more seriously. Clumsy or not, the professor succeeds in awakening Törless' interest in the serious philosophical approach of mathematical problems, but the boy's initial enthusiasm for Kant's philosophical work ends in

\footnotetext{
${ }^{20}$ Cf. Musil's own experience as an adolescent Chopin-enthusiast and voyeur of the prostitutes; TB I, 158.
} 
Rosenfield, K. H - Musil's Idea of Poetic Mastership

repulsion ${ }^{21}$. His impetuous mind is unable to follow the meticulous small steps of this grand systematic thinker. In the last third of the novel, the narrator shows how Törless' reluctance to develop a serious intellectual effort springs from his sensuous tendencies and his insistence on the superficial attitudes of the aesthete. Instead of grinding through Kant's philosophy, he falls back on the reminiscences of the intense musical and erotic impressions of his childhood. He dreams with the intense feelings conveyed previously by the music of Italian operas and the fantasies of the singers and actresses performing them. The mystery of these feelings is intensified by his willful intention to hold them up as a sacred vase: he starts to feel like "a holy man with celestial visions" (T 92). The narrator highlights the ridiculous artificiality of this mystifying drive and creates a strong anticlimax to Törless' effeminate enthusiasm: "He felt like a chosen one. Like a holy man with celestial visions; - because he knew nothing about the intuitions of great artists." (T 92). Immediately after this passage, the narrator reports Törless' artistic failure to put the enlightening experience of the mysteries of music into writing - "the colorful brightness in his mind dimmed" (T 92). The next paragraph links this failure to the report of his intellectual failure to come to grips with Kant: "the Kant episode was almost totally overcome" (T 92). The 'almost' indicates what the next page will specify: Törless cannot suppress a feeling of shame for having "sneaked out" of the more difficult task (vorbeigedrückt T 93) and while his mind pursues "like a hunter" (T 93) all the sensuous details linked to Basini's erotic attractiveness, there remains in the back of his mind "the reluctant confession of a failure". Musil makes it clear at the end of the next paragraph that this failure is both artistic and intellectual, and that it is due to Törless' insistent abuse of both his intellectual and aesthetic abilities. These have not been developed appropriately, but remain confused in an ambiguous and potentially perverse way:

As soon as the vague feeling [of intellectual and artistic failure] surfaced, his
attention lost the ease with which we watch the development of a scientific
experiment. There was a bodily attraction emanating from Basini, a stimulus as
if when sleeping in the proximity of a woman; one feels as if the body under the
sheets might be uncovered at any moment. It was like a tickling in the brain,
which initiated in the consciousness that it would be enough to stretch out one's
hand. It was the very thing which often drives young couples towards excesses
going far beyond their sensuous desires. (T 93)

\footnotetext{
${ }^{21}$ Musil occasionally accused himself of having been prone to this kind of neglect. Cf. his remarks in the notebooks about the importance of scientific and philosophical seriousness like Descartes': Descartes TB I: 776 .
} 
The narration suggests that there is a link between Törless' lazy reluctance to pursue more seriously his potentially artistic and intellectual gifts and the impure and potentially perverse aestheticism of the "tickling brain" which uses conscious thoughts to drive his sensibility to excessive hedonism.

This and other passages show that the novel Törless is not conceived as a mere representation of the hero's feelings. Neither the author nor the narrator judges his feelings to be in themselves worthy of artistic representation (cf. FRIER 1976: 311). Törless' feeling of shame also shows that he is not merely passive, prone to feeling but not to thinking (Id.: 312), but that he is unstable, abusing his forceful enthusiasms and choosing not to develop his passionate energy into artistic activity. The conclusion suggested by the novel is not quite, as FRIER (and other critics after him) affirms, that "thinking is useless," nor that the inexpressible otherness of the almost mystical sensuousness "is stronger than Törless" (Id.: 312). Musil's narrator tries to point out that Törless is, on the contrary, very active, both as an intellectual "thinker" and as a sensuous feeling person, but dissipates his intellectual efforts by diverting them towards the enhancement of a redundant sensitivity, which menaces his intellectual and his artistic gifts and has potentially perverse twists.

There are other passages which illuminate these decisive differences that lead to Törless' failures, and which are later confirmed by his development as a rigid and prudent aesthete. A few pages after the ruminations about Törless' Opera enthusiasm, a nocturnal scene shows Basini leading Törless up to the red chamber where he suddenly undresses: Törless is struck by the beauty of Basini's body (T 98). But again, this first, startling revelation of beauty does not lead him to the intriguing question where the difference between erotic attraction and aesthetic beauty lies. On the contrary, the potentially inspiring revelation is quickly overgrown by homosexual attraction and by the feeling of shame (von Scham unterdrückt T 99).

Analogous shortcuts and lazy simplifications also supress Törless' initially lucid perception of Reiting's and Beineberg's abject sadism. Törless does not lack the insight or the courage to oppose them. On two occasions, he verbally rejects their senseless, imbecile brutishness. He even knows that he should fear their blunt power-thirsty cruelty when he learns from Basini about their dismissive attitude towards him, and he is conscious that there may come a moment when he would have to decide and risk everything in order to break free from their intrigues (T 100). But in the end, he accepts 
precisely these intrigues and becomes an accomplice to the stratagems by which Reiting and Beineberg transform Basini into a scapegoat and stage before the school committee the farce of their brotherly moral efforts to improve a fallen schoolmate.

Neither the narrator nor the author of the novel can thus be considered indifferent as to the dangers of aestheticism in Törless' trajectory. Musil seems to have let a crucial problem write itself out: the task of the serious writer consists in a tough working through of feelings and thoughts and their fusion into an artistic whole. Although Törless embraces aestheticism, Musil and his narrator do not. For Musil, and his narrator, aestheticism is a reactive inflation of feelings which art investigates as to their specific constellations (Gestalt), hold them up against the horizon of scientific and philosophical thought. The artist's effort is to introduce more precision into the emotional domain, showing the infinite small steps which entangle and fuse together the willful consciousness and the feelings, and the perversions which can be achieved by the skillful interweaving of the two domains. The serious artist, on the contrary, has a responsibility to work against the easy myth-making of literary dilletantes and musical enthusiasts (Wagner, Chopin were particularly fashionable composers for cultish fin de siècle cliques) and break free from scientific and ideological mystifications. Musil insistently hinted at the aesthetic-artistic dimension of his novel. This artistic puzzle, which links together the aesthetic, the rational, and the ethical domains, was then a thrilling discovery which would become more and more important to him in later years $^{22}$.

Törless seems to have been for Musil, both as narrator and as author, the embodiment of a somewhat lifeless aloofness, which prepares the future aesthete, whose "ironic sense of what is correct" (T 111s) springs from the refusal to connect his feelings and doings to his sharp intellect. Thus he remains shallow, wrapping superficial and conventional truths in fine, almost snobbish, aestheticizing rhetoric.

\footnotetext{
${ }^{22}$ In spite of a few fruitful insights into the importance of the aesthetic and creative dimensions (MULOT; KNÜPFERMANN; REIS), these aspects have not been sufficiently addressed by criticism - neither in Kisch's Obituary, cf. TB II: 204; nor in Thiher's understanding of Törless' cathartic experience, which would transform the novel into a modern Bildungsroman. Thiher draws attention to these proleptic anticipations of Törless' future, but he interprets these anticipations as the narrator's intention to "reassure [the reader] that the boy will turn out all right" in the end (THIHER 2009, 51), his only problem remaining the belief "that after Schiller and Goethe it was not worth the effort to write any more poetry" (GW, 6, 79; THIHER 2009: 77). LUSERKE-JAQUI, considering the erotic, psychological and moral biases of the narrative, underlines the tension between an uncensored presentation of authentic adolescent sexuality and the final withdrawal to of the narrator to the "moral mainstream" (LUSERKE-JAQUI 2007: 169).
} 


\section{The Problem of Aestheticism in Musil's Life}

This latter aspect of Törless probably mirrors a biographical experience - Musil's ambivalent friendship-and-rivalry with the sophisticated Johannes von Allesch, whose literary pretentiousness has some parallels with Törless' attitude. But Musil was not merely describing a friend. Törless' haughty aloofness was something that Musil feared in himself, and the path of aestheticism was a temptation against which Musil struggled as he matured. Striving for mastership (not just the journalistic skill of the successful Schriftsteller), Musil wrote his first novel in order to come to embrace his poetic task in his own terms. For him, the ethic and aesthetic consistency of the poet had to be founded on an accurate recognition of the specific particularity of lived experience. In his earliest writings, he mused over the difference between rhetorical conventions and authentic emotions. He wrote down a series of observations about the processes which fix feelings in historical conventions and habits, i. e. generally comprehensible notionsof-feelings (or notions which induce understandable and transparent feelings), as opposed to the artistic struggle to let real emotions (or real aesthetic experiences) write themselves out in dense literature, which interweaves the previously inexpressible with complex thoughts ${ }^{23}$. What distinguishes the poet (the masterful, creative individual) from the aesthete or the conventional average person (the Mitläufer) is the constant, strenuous effort to create a subtle and artful balance among body, mind and soul, concept, intuition and action.

In our reading, Törless' crisis dramatizes the decisive (and biographically relevant) difference between two possible trajectories open to a talented, sensitive and intellectually sharp young man, a fictional alter ego of Musil himself. As so often happens in Musil's novellas and novels, he toys with one of his own temptations: the weaknesses of the young man on the brink of missing his chance to face the aestheticand-ethical challenge which can transform him into a remarkable person or artist. Like his more robust and violent friends, Beineberg (with his cheap mysticism) and Reiting (the demagogue and dictator to be), Törless, too, will yield to a sadly fixed attitude, denying his own feelings and doings (for example, in his homosexual experience with Basini). He will not reject them for moral reasons, but for the fear of mixing with the

${ }^{23}$ Cf. TB I: 155, where Musil reflects, on the 8th of August, 1905 on an essay about Renaissance sensibility (Renaissanceempfinden), published in the Neue Rundschau. 


\section{Rosenfield, K. H - Musil's Idea of Poetic Mastership}

commonplace. The narrator's anticipations of Törless' later reactions show how he will protect himself with the typical shield of the versatile aesthete, the detached connoisseur who artificially cultivates his feelings, trying consciously and willfully to go beyond the stereotypes of convention and everyday triviality (cf. "Literati..." P 1220; PS 84 s).

Musil sees the problematic aspect of aestheticism lurking in certain attitudes and mental practices which he observes in his surroundings. This becomes clearer when we look at the notebooks of that period. In the very year 1905, when working on the final draft of his Törless, Musil noted a conversation with his friend von Allesch, in which he tried to come to grips with the difference between the aesthete and the artist (or the serious critic):

5. VII, [1905] Today, after Schumann's seminar, I talked with von Allesch and a few others [...] about Huysmans, whom Allesch praised immensely. I said that I didn't like Á Rebours. Von Allesch: "oh, but that is very fine stuff, particularly his style. There are such subtle aesthetic beauties..." I objected that "this subtlety is slightly artificial; there is nothing real, nothing [convincingly] concrete or tangible". Allesch: "what does 'real' mean [in literature]? And why would it be a fault to be artificial?" (MUSIL TB I: 152s, Notebook 11)

Musil is irritated with the cultish snobbery of Allesch's know-it-all attitude, which is so at ease in the world of art that he needs no longer wonder about its relation to real feelings and thoughts ${ }^{24}$. He calls this attitude "sensitizing Baconism", and tries to ward off the menacing presence of "the type of the aestheticly sensitive" person that surrounds him:

I am, myself, morally sensitive. Particularly since the time of my passion for Valerie. In the old day I ran with the aesthetes. But later, I started considering them to a certain degree as part of the greenhouse culture.

Constructed feelings, paper emotions. And now I run into a man who has all these cultural associations available. He pretends that he can feel feelings which I can only spell by name and concept. I have to figure him out; which puts me into an excitement like in the old days when I entered, as a half-barbarian, into the circle of students at the gymnasium. (MUSIL TB I: 152-3)

Musil's Notebooks provide a few more enlightening insights into his efforts to define the task or the writer (poet, Dichter) as that of discovering possibilities which might

\footnotetext{
${ }^{24}$ Cf. TB I: 152s; Allesch, the versatile aesthete, corresponds to the model of the over-sensitive aesthetics of the decadence, like Huysmans or George.
} 
bring into a better equilibrium the spiritual, the intellectual and the emotional perspectives on human experience (cf. also TB I: 98 and 152-155):

This morning, strolling over the Franzensberg - on that path passing above the whorehouses whose backyards are in plain sight. In my head there were those extenuating movements by Paderewski. I reflected. If somebody were to play them constantly within my soul... I felt that I would totally withdraw from life and that I would focus wholly on that thing, because life is unable to provide something equivalent. This moment which now wraps me in veils of soft light, it will die again, like all thoughts.

[...] There is nothing we can do: our lives last for a certain time and every hour is like a gaping void, death's offspring, which has to be filled. And one cannot fill it with those subtle things. (MUSIL TB I: 158 and TB II: 821)

While writing his first novel, Musil seems to break loose from the hypersensitive aesthetic experiments which prevailed during the period he spent in Brünn, and he starts to blaze the trail towards his conception of the subtle dividing line which separates the distanced detachment of the aesthete from the artistically important openness and experimental irony of the serious author. Beyond the ideological stereotypes and cultural clichés of his figures appears das weite Land - the wider horizon of possibilities he plays with.

A few years after his first novel, in his essay The Mathematical Man (1913; cf. P 1004-8; PS 39-43), Musil insisted on the importance of this approach and challenged the artist not to "beat the drums against intellect and forget that without intellect - apart from exceptional cases - feeling is as dense as a blockhead." (PS 42) Not deep feeling, but

[...] intellect gobbles up everything around it, and as soon as it lays hold of the feeling, it becomes spirit. Taking this step is the task of writers. To do this they don't need to learn some sort of method - God forbid, psychology or the like but they only have to set high standards (Ansprïche) ${ }^{25}$. (MUSIL 1990: 43)

Implicit in the German Ansprüche is "higher standards" or "more challenging aspirations" than the average person, the person who is satisfied with simplified forms of expression and clichés, with (shallow) entertainment or the sort of false (already conceptual) wisdom of the "big-time writer" ${ }^{26}$ - a figure which will take form in the

\footnotetext{
${ }^{25}$ We slightly alter the English translation ("but only aspirations"), because Musil here uses Ansprüche as a synonyme for anspruchsvoll sein.

${ }^{26}$ Cf. P 1330 s. ("Die Ziele der Dichtkunst") / PS 46s., "The goals of Literature".
} 
Rosenfield, K. H - Musil's Idea of Poetic Mastership

character of Arnheim in The Man Without Qualities. Arnheim's polished refinement, his combination of easy eloquence and appealing essayism, draws additional power from his immense economic power and wealth. For all its brilliance, however, it remains lifeless and lacks the thrill of real experience. That Musil had higher aspirations also becomes clear in a few lines of Nietzsche that he copied in the late 1930s:

A quotation drawn from Nietzsche: "the truth is that the imagination of the artist or the intellectual (Denker) produces constantly things that are good, medium or bad; but the trained and piercing judgment [of the important artist or thinker] rejects, selects..." (TB I: 939) ${ }^{27}$

In other words, what Musil presents as Törless' confusions - ranging from sensitive, erotic and intellectual experiences to shocking indifference, reactive snobbery, aestheticizing hedonism and complicity with sadistic cruelty - is not, as such, strange to anybody's experience (and less so to Musil's own ${ }^{28}$ ). Neither the average person nor the poet is immune to the wide range of bad, medium and good feelings and actions. What Törless finally becomes is the result of a continuous pattern of choices that he makes. Musil thinks it necessary to anticipate the - as yet unforeseeable - future of this boy, and to predict that his proclivity to aestheticism will deprive him of a career as a poet. It is as if Musil were obscurely starting to imagine his own trajectory, his breaking loose from an imitation of the aesthetic experiments with sensations and feelings which were fashionable in the decadent and expressionist movements. And while he still actively pursued a career as a scientist (he finished his doctoral thesis on Mach more or less at the same time as his novel), he also became critical of the abstract form of expression of philosophical or scientific prose. Although attracted by sharp scientific and philosophical distinctions, Musil's aim was to fuse them into the tangible, particular experience of individuals that he and his contemporaries could (or should try) to understand feelingly ${ }^{29}$. The hovering otherness of feelings and synaesthetic perceptions

\footnotetext{
${ }^{27}$ During the difficult years before his death in Swiss exile, Musil incessantly returned to his previous conceptions of art, culture and the possible role(s) of the artist and intellectual in contemporary society; cf. Heft 30 TB $777-779$ and 911-966.

${ }^{28}$ Biographical research has made clear the factual material used for the construction of the story (cf. SCHRÖDER-WERLE 2001: 31-53).

${ }^{29}$ Jürgen THÖMIG has shown Musil's subtle techniques which dissolve linguistic and emotional stereotypes, altering creatively the crystallized in clichés in order to sensitize his readers in a livelier and spiritually more challenging way (ТHÖMIG 1974: 319s). The fact that many readers resist this simultaneously aesthetic and intellectual challenge, or find it boring, should not make us look for Musil's ideas exclusively in his critical work. Musil's essays are of great importance, but we should not forget
} 
Rosenfield, K. H - Musil's Idea of Poetic Mastership

is neither totally irrational, nor entirely inaccessible to rational investigation. These hovering constellations full of potential thoughts are, on the contrary, waiting to write themselves out in a way that dissolves the ambiguities of (mere) metaphors and images.

Trying to introduce precise analytic reflection into the domain of poetic imagination, Musil strove to influence his readers through his fiction. He wanted to make them more perceptive and discriminating, inspiring them to strive for relevant distinctions and choices. His particular aim as a poet was to avoid the corrupt use of (everyday) language which inevitably leads to corrupt moral practice. This is the "far reaching horizon" that Lukács praised in Musil's work as early as 1933: it is the hovering life of the poet suspended between the aesthetic and the ethical dimensions. The complexities of this horizon should not disappear through an excessive focus on Musil's intellectual and satirical achievements, which made him, for Lukács, the paradigm of the intelligenzia of his time. Lukács admires Musil as a "precise experimentalist, a rational engineer for the refined motions of the soul of the intellectual elite [...] whose horizon, however, is much grander and far reaching than the one belonging to those he satirizes". ${ }^{30}$ Musil himself welcomed sociological, philosophical and anthropological considerations as an antidote to the excessively psychological or biographical "misunderstandings" and misreadings of his early works ${ }^{31}$. Nevertheless, he also regretted the failure of contemporary critics to perceive the peculiar blend of critical acuity and irony with the passionate intensity of lively images and figures, which is the achievement of his fictional writing ${ }^{32}$. He hoped that readers would expose

that we owe their existence mainly to hardships and economic necessities which made it difficult for Musil to pursue his poetic vocation.

30 Apud NüBEL 2006: 138s, who analyses G. Lukács' Musil reception in his essay Totentanz der Weltanschauungen.

${ }^{31}$ Cf. GW II: 966, where Musil denies any personal or realistic implications of his own experience with the psychological and sexual experiences of his novel's characters - a denial so insistent that it has led to discoveries proving the contrary. Several critics (like Carl Corino, Peter Henninger and Karl Dinklage) have shown the striking analogies between the names of Musil's colleagues at the military convent in Mährisch Weisskirchen and the characters in the novel: Boineburg, Reisinger and Fasini reappear as Beineberg, Reiting and Basini (cf. SCHRÖDER-WERLE 2001: 44-54).

${ }^{32}$ Musil frequently returns to the difference between cold intellectual reflection and the same thought sustained by "passionate energy", which brings out a vibrant beauty, some inexpressible quality of the same facts (cf. TB I: 214). To be intrigued with this difference is the challenge of the Poet. Törless' ultimately refuses to acknowledge this intriguing quality, as, for example, when he rejects and represses the experience of the seductive, feminine beauty of Basini's body. The Poet would retain this vision as something illuminating, as a revelation which is quite different from the physical, sexual experience he lives through, whereas the aesthete prefers to remain ambiguously distanced: not repressing it altogether, but freezing it in the refined formulae which Musil mentions in his proleptic anticipations of Törless' later life as a prudent aesthete, who sacrifices his gift as a poet to correctness and formality. (GW VI: 78) 
Rosenfield, K. H - Musil's Idea of Poetic Mastership

themselves imaginatively to the lived experiences of his heroes' thoughts and actions (and the tricky possibilities ensuing from them) in a conceptually unarmed and thus more sensitive manner, so that the aesthetic experience would make them reconfigure, rather than just rethink, their preconceived ideas and prejudices. We can see this in one of the outbursts registered in his notebooks:

If only critics asked themselves as to the characters the poet creates in a book: what kind of people are these [...] instead of dwelling on principles, laws and artistic theories they don't have a clue about? (TB I: 431s).

Birgit NÜBEL is well aware of the author's complaints about critics who read a Poet's work with conceptual intentions ${ }^{33}$. This is probably why she finishes her book with an apologetic quotation from Maurice Blanchot: "I fear that Robert Musil's oeuvre is more commented on than read, [...] it is so close to [being itself] a commentary that it [...] seems to demand more of a commentary than a reading." 34 Without putting into doubt, in the least, the importance of the essayistic context, which becomes increasingly relevant after the Wende of the 1920s and 30s, the present essay proposes a narrower focus: we will contextualize the difference between the poet and the aesthete present in Törless with a few revealing annotations in the Notebooks and in some passages of the Essays. Törless' experience can be read as a glimpse of Musil's own attempt to abandon aestheticism and to search for an authentically poetic trajectory. As Musil claimed, Törless is neither a realistic account of personal experiences - psychological, sexual, biographical -, nor a realistic representation of educational or social discontent, but the unfolding of an embryonic idea ${ }^{35}$. Although Musil wrote Törless before consciously deciding to be a Poet, he anticipated, poetically, the later developments of his career as a Dichter. This idea of what distinguishes the poet from other possible roles, which he

\footnotetext{
${ }^{33}$ Barbara NEYMEYER's “Utopie und Experiment" or Birgit NÜBEL's Habilitationsschrift, Robert Musil. Essayism as a Mode of Selfreflection of Modernity, show how Musil's Notebooks and Essays prepare the way for the self-reflective tendencies of $20^{\text {th }}$ century modernity (cf. NEYMEYER 1996 and 2000; NÜBEL 2006).

${ }^{34}$ NÜBEL 2006: 496, quoting M. BLANCHOT, Der Gesang der Sirenen. Essays zur modernen Literatur, "Musil", 1962: 184-206.

${ }^{35}$ Cf. P 947: in an autobiographical fragment of the 1930s, Musil remembers his astonishment at the interest of psychologists and pedagogues in his first novel - an interest which he considered almost as an insult (ich fühlte mich beinahe beleidigt). Only later did he realize that he had written something "which in the course of time, revealed itself as typical" for educational and psychological issues. The same is true as to the political and social implications: in 1936, Musil recognized that "Reiting and Beineberg anticipate the insurrectional officers who are bound to become the leading type in this world" (TB I: 834); a year later, he saw their live counterparts (Reising and Boineburg) as the "dictators in nucleo" who conceive of the "masses" as a material to be oppressed (zu zwingendes Wesen) (TB I: 914).
} 
Rosenfield, K. H - Musil's Idea of Poetic Mastership

grasped, for the first time, in Törless, will later be developed in countless and everincreasing distinctions - as, for example, when Musil struggles with the subtle differences of tone and style which distinguish the serious poet from the successful writer Arnheim, or when he muses about what separates the poet from the aesthetic dilettante Walter, or when he measures the distance that separates his partial alter ego Ulrich, who is a prototype of modern skepticism, from a great author who is capable of handling and embodying aesthetic and ethical density.

Musil is famous for his peculiar, and peculiarly poetic, blend of thought and feeling. This is already evident in the first novel which hinges on the epiphanies - both positive and negative - of a dimension that is incommensurable with cold and exclusively intellectual reflection. In trying to come to grips with the distancing effect of irony, Musil seeks to moderate the playful aloofness of the ironic gesture in a "fundamentally ironic attitude" (ironische Grundhaltung) which he does not wish to be understood as a "gesture of [intellectual] superiority, but as a form of struggle", an irony which remains open to "vivid scenes and fantastically passionate [moods]" (TB II: 941). In other words, the irony must not become, in Musil's conception, a strictly intellectual and rational distance, but a hybrid hovering between indifference and passionate involvement.

An analogous concern is visible in Musil's early critical observations concerning the formal differences between the classical novel of the $19^{\text {th }}$ century and the narrative fiction of his own day. He argues that the classical mode of narration creates a delightfully welcoming tension which draws the reader into the midst of the events and characters and grants him the freedom to come to grips with the narrative all by himself. The essayistic mode, by contrast, guides the reader's attention and controls his awareness, pressing it towards conceptual consciousness:

On technique: We have now forgotten what older novelists knew all too well: to create suspense! We only know how to provoke fascination in our readers. That means, we seek to write wittily and to avoid boring passages. We pull our readers along in all we go. Suspense, however, means to make the listener look forward to what is coming. Let him accompany [the narration] thinking and reflecting, let him walk alone on the path that has been shown. This confers a certain cosy feeling of sharing things. The humoristic novel depends entirely on this feeling. Writers suggest a situation which is preparing itself and the thought forms itself: what will good old $\mathrm{X}$ do now again? This demands much detailed outlining on the different types. However old-fashioned this may seem, it is a 
piece of the artistic effect as opposed to the effects produced by philosophers and Essayists. (TB I: 99s) ) $^{36}$

Musil thought that both approaches - the essayistic and the poetic modes of expression were valuable, and he attempted, as he said, to "fight with both arms". ${ }^{37}$ At precisely the moment when he was writing Törless, he began to be increasingly critical of modern artistic experiments and the cultish, intellectualized attitudes (like Allesch's) which accompany "art scenes". Not to yield to this kind of superficial consensus was, for Musil, the challenge of the great artist, the Dichter, whose high standards are satisfied with true mastership only. The serious writer must avoid both the empty conventional finesse of the aesthete and the bloodless conceptual grasp of the philosopher, combining in masterful balance precision and soul.

In Musil's notebooks, the sober, businesslike juxtaposition of objective observations with the pitiless analyses of intimate processes (his own and other people's) provides raw material for the fictional project. Thanks to his background in science and philosophy, Musil saw, much more sharply than other artists of his time, the problematic status of the poet caught in the complexities of modern society, in which the specialized philosophical and scientific disciplines seemed to leave little space, and even less prestige, for poetic subtleties.

As the Austro-Hungarian Empire dissolved around him, its final upheavals made him particularly sensitive to (un)acceptable political and ideological compromises, confronting him very realistically with the social, communicational and economic implications which tend to conflict with the inherent concentration and density of poetic thought. The latter belong, according to Musil, to "another condition" (anderer Zustand) than rational understanding and calculation. Nevertheless, he was able to vindicate a place for poetry and poets within, and not apart from, modern society's new, prosaic context of scientific knowledge, competitive technological interests, and functional rationality. He set out to create fruitful relations between the non-rational

\footnotetext{
${ }^{36}$ Birgit NÜBEL analyzes the "self-reflectictive tendencies" of the modern, essayistic novel and shows how intensely G. Lukács reflected about his own essayistic activities as he studied Musil's innovation in The Man Without Qualities. Nübel quotes Lukács' idea that this tendency would provoke "a pivoting of the aesthetic into the essayistic effect" (cf. LUKÁCS, Werke, Bd. 11, "Die Eigenart des Ästhetischen" 1963: 726; cited by NüBEL 2006: 137)

${ }^{37}$ Cf. Musil's critical evaluation of Kafka's and Walser's narratives, whose playfulness (excessive in Musil's opinion) loses sight of this balance. See: "Literarische Chronik" (1914), P 1465-71.
} 
(not to be confused with the irrational) and the domain of scientific and philosophical precision.

Confronted with artistic programs and movements that proposed a more immediate access to feelings and sensations and turned their backs on scientific precision and philosophical thought, Musil conceived of feelings and imaginary intuitions as exceedingly complex constellations which require more and more precise investigation. In his view, rational thought differs from poetic thought just as conscious apperception differs from the not-yet-conscious perceptions (a distinction which comes close to Leibniz's Monadology ${ }^{38}$ ): the latter come as nebulous, fleeting constellations, which Musil compares to the ephemeral intensity of perfume or of hovering clouds, whose swiftly changing constellations are difficult to grasp in conceptual language. Nevertheless, a serious writer can convey glimpses of this other condition, inasmuch as he can makes his readers feel the "quarters and eighth degrees" which distinguish the plasticity of these forms of feeling and thought from the determined and well-defined categories of rational thought. The method of "the minutest steps", of sharper and more sensitive observation, can train the "soul" (a domain at the meeting-point of the sensitive and the intellectual) to make feelings accessible to understanding and intellectual considerations. This is the task of the serious artist, poet and writer.

For this and other reasons, Musil rejected the vague conceptions of the irrational that were current at the turn of the century, derived largely from an excessive emphasis on the benefits of immediate feelings and emotions and grafted onto a biased understanding of Nietzsche's Dionysian principle and a metaphorical absorption of psychoanalytical ideas ${ }^{39}$. In his The Man Without Qualities, Musil develops the misreadings, the more or less sophisticated applications and popular simplifications of these imaginary theories in a wide range of fictional characters like Walter, Clarissa, Diotima and Arnheim.

\footnotetext{
${ }^{38}$ A Portuguese translation of Leibniz' Monadologia is available online: http://www.leibnizbrasil.pro.br/leibniz-traducoes/monadologia.htm. See paragraphs 12 and 14.

${ }^{39}$ Patrizia MCBRIDE has shown how literary critics like Herrmann Bahr induced a large public to accept as scientific facts vague analogies between theories like Ernst Mach's empiricist atomism (in particular, the notion of fluidity or instability of the Ego) and Nietzsche's metaphorical philosophy of Greek tragedy. (cf. MCBRIDE 2006: 42s).
} 
Musil believed that serious literature had to enable the reader to feel and understand (at least to a certain degree) how different characters "fit together" the chaos of impressions to construct their world views, and the attitudes, habits and stylistic tricks that allow them to present things and ideas according to their own or others' mental and senti-mental routines. In his essay "Profile for a Program", he demands:

[...] mathematical daring, dissolving souls into their elements and unlimited permutation of these elements; here everything is related to everything else and can be built up from these elements. But this construction demonstrates not "this is what it is made of", but "this is how its pieces fit together. (P 1318; PS 13)

This is why, for Musil, Gestalt psychology ${ }^{40}$ is more important than the psychoanalytical clichés too quickly picked up by artists and literary critics. Great literature has to offer a welter of examples - not one model to be followed - which sharpen our perception of differences and possibilities not yet realized.

Shortly after writing Törless and Unions, Musil began collecting examples of characteristic modes of expression, the specific "styles", variations, or, as he wrote, "permutations," of the very same contents and elements. The two couples, Diotima and Arnheim, Agathe and Ulrich, are conceived of as such experiments with thoughts and feelings. Both couples struggle with the "inexpressible" enigmas that had confused Törless - love, the soul, elevating ideas, spiritual transcendence - but the result of their respective handling of these elements could not be more different. Musil writes in his notebook no. 21:

"juxtapose" [the two couples and their struggle with] "the inexpressible". "Wheras Ag[athe]: A[nders/Ulrich] notice this [inexpressible yearning] in themselves, it is played out as a pretentious hesitation between D a Arnh" (TB I: 588)

After that opposition follow numberless examples of the specific styles expressing Diotima's and Agathe's feelings. Diotima's style is prophetic sentimentality:

A time will come - and there are signs that this time is near - in which, may be, our souls can behold each other without the mediation of the senses.

\footnotetext{
${ }^{40}$ For a synthetic view, cf. BONACCHI 1998.
} 
Occult powers awaken around us, magnetism, telepathy and levitation / Anders finally takes her to such meetings / scientific spiritism - materialization. (TB I: 588)

This almost liturgical soul-mongering and her tendency to occultism contrasts with Agathe's more down to earth observation:

Presentiments, the strange impression of an encounter or of the look [of another person]; a decision, we will never know why.

Do we not all spend the greater part of our lives in the shadow of an event which has not yet happened? (TB I: 589)

What matters for Musil's poetic enterprise is the exact tone of such quotations, their intonation and (often abusive) use of notions like spirit and soul, ideas and intellect, which tend to become meaningless (and prone to propagandistic abuse) when they are carelessly treated as "bundled packages": as conventional commonplaces and clichés repeated in journalism and small talk.

\section{The Ethical Dimension of Serious Literature (as Opposed to Aestheticism and to Ideological Definitions)}

The young Musil was highly suspicious of the aestheticism of his time - as well as being nervous about what he felt to be his own insufficient knowledge of art and literature ${ }^{41}$. As he transposed his experiences into fiction, he turned his aesthetic insecurity, worrisomely contrasted with Allesch's highbrow sophistication, into the unfavorable relationship that Törless maintains with his older colleagues, who pretend to have solutions to the enigmas that trouble Törless. Törless' uncanny emotions and fantasies would require "high standards" of senti-mental elaboration; but the school does not provide him with an adequate environment. On the contrary, the school, like his parents, offers him only a homemade sentimental moralism; while his older schoolmates offer an unrestrained brutality, physical and mental. The reactions of the three boys to the

\footnotetext{
${ }^{41}$ Musil's education and training were much more turned towards mathematics and the exact sciences than towards art and literature. This made him often feel uneasy and (over) competitive in his relations with colleagues and friends more familiar with the literary world.
} 
outdated and oppressive educational and moral ideals of the Bildungsbürgertum ${ }^{42}$ outline three types of attitudes which were characteristic for the building up of the cultural impasse, in Austria and Germany, to which Freud much later attached the memorable phrase "Civilization and its Discontents". But Musil did not do what Freud did. From the beginning of his writing life to the end, he tried to avoid unilateral explanations of all kinds ${ }^{43}$. From early on, he identified the countless daily attitudes, each apparently innocuous, which contribute to pave the roads to moral degradation. He was acutely conscious of the daily use of sentimental and hypocritical clichés which prevent people from perceiving the reality, the laws, and the rhythms of real life and experience. Törless' future withdrawal to aestheticism is not neutral. It will weaken his precious combination of sensitive, passionate alertness with keen scientific thinking. It will turn his mind, which still searches in its youth for "natural", precise, mathematical explanations, backward - perhaps, like Beineberg, to myths of unity and ancient wisdom, perhaps to the unity of Greek (or Indian or medieval) philosophy and art, perhaps to some other easy illusion. In his early youth, Musil had felt the enthusiasm for the forceful beauties of Classical Greece and the Italian Renaissance as interpreted and praised by Goethe, Nietzsche, and Jakob Burckhardt; but he quickly perceived the dangers of the transformation of these ideas into educational or cultural models for contemporary society ${ }^{44}$.

What were, or are, those dangers? In Musil's sensitive, alert, and precise analyses, the aestheticizing cast of mind fits perfectly into the other malign tendencies of reactionary culture and politics in Austria and Germany. Nietzsche's will to power,

\footnotetext{
${ }^{42}$ Musil's later novel The Man Without Qualities, represents Lindner and Hagauer as the educationspecialists whose programs present outdated ideas as modern and promising perspectives.

${ }^{43}$ Musil does not deny the merits of the emancipation movements of his time, only the unrealistic and unscientific salvation-attitudes attached to them. What he criticizes is the combination of a salvationpromise grafted on a unilaterally singled-out unique explanatory theory: incest taboo and sexual repression in Freud's case, the forgetfulness of pre-Socratic Being, in Heidegger's, the longing for religious integrity of catholic conservatism, for aesthetic holism in the arts or the calls for national unity by the Pan-Slavic or the Pan-Germanic movements; or, later on, the formulae of communist and Stalinist panaceas.

${ }^{44}$ Cf. his analyses, in the Notebooks, of Ricarda Huch's Blütezeit der Romantik (published in 1899, second edition 1901; cf. TB I: 137, 3 April 1905) and Ellen Key's Die Entfaltung der Seele durch Lebenskunst (June 19, 1905, TB, I, 151). Although Musil frankly admits that he shared precisely this enthusiasm for the "age in which romanticism flourished" (Blütezeit der Romantik) he quickly identifies the regressive trend and the sentimental stagnation of this kind of enthusiasm which remains blind to the challenges of modern science and technology, politics and economy. It feeds on impoverished scholarship which transforms Goethe, Nietzsche and Burckhardt into popular, journalistic recipes, a generalized form of demagogy which takes form in The Man without Qualities as the Diotima-syndrome: the vague enthusiasm of the (half) cultivated public that gets its ideas from literary supplements and illustrated reviews.
} 
Burckhardt's praise of the Italian princes, and Nietzsche's dreams of a Dionysian revival of tragic heroism or the illusions attached to forceful liberation of the deepest passions through the spirit of music or through erotic experiences - all the vagueness of these regressive forms of idealism tended to channel the most precious talents and efforts into the nets and "movements" of political and ideological "decisiveness". In the larger social and political context, these ideas, formerly exciting and even liberating, could only be devastating.

In the following decades, Musil wrote and spoke a lot about the dangers of this "longing for decisiveness" (Sehnsucht nach Entschiedenheit, MoE: 1128; MwQ 1995: $1228)^{45}$. The clearest comes from his notebooks:

Long before the dictators emerged in reality, our era produced the (climate for) their spiritual veneration. Have a look at Stefan George. And also Kraus and Freud, Adler and Jung. Or see Klages and Heidegger. The common denominator is probably the desire for leadership, the nostalgia for the essence of the savior. Would this be characteristic of leaders? For example, firm values and formulae which can, however, be understood in totally different ways. (TB I: 896$)^{46}$

The quotation about the dictators points out that the danger does not lie exclusively in the fascist and Stalinist dictators, but in the entire range of emotional, sentimental, aesthetic tendencies and their yielding to intellectual laziness, compensated by sudden passionate explosions of activism and Dezidiertheit (decisiveness). The aesthete, who misses the intellectual challenge of his obscure feelings and longings, who fails to elaborate, step by step, the inner workings of the intense emotions which easily carry us away, is the most vulnerable of social types - vulnerable, particularly to the pressures, menaces and seductions of tyrannical power (the Reiting type) and the theatrical staging of ritualistic esoterism, which tends to draw on legends of ancient wisdom and a sentimental longing for the lost perfection of bygone cultures. Embittered by the terrible turn of contemporary Austria and Germany, Musil reiterated, in his diary, that all the admired aestheticizing artists, all the philosophical, psycho-analytical and ideological

\footnotetext{
${ }^{45}$ Cf. Klaus AMANN's detailed analyses of the political implications of Musil's literary and critical essays: "Robert Musil: Literature and Politics" (2007a: 60s) and the more recent Book, Robert Musil Literatur und Politik (2007b). Musil's essays and annotations follow all the phenomena of the rising fascism: the medievializing aesthetics of the book-burning in May, 1933, carried out by students under the patronage of Göbbels and with radio broadcasting (cf. AMANN 56); the mythicizing rituals of the "consecration of the banners" (see below, Appendix no. 2) and the like.

${ }^{46}$ TB I: 896 [summer, 1938]
} 
myth-and-culture-mongers, contributed to the general mindlessness of their own culture, which sold itself out to National Socialism. Not only the avowed Nazis like Heidegger, but even Freud had this effect on the people who would soon salute Hitler.

Musil was of course smart enough to know that Freud was not a fascist or a Bolshevik. It was not the beliefs or commitments of these writers, but their mental habits and their reaching out for mythical patterns and etymological fantasies that made them bad counselors. What Musil noticed in all of them was a one-sidedness, a preference for unilateral methods of investigation. Musil feared that the quick and easy translation of their work into popular formulae and journalistic jargons would make it easy for demagogues to use these stereotypes effectively, manipulating the opinions even of most intellectuals, not to mention the uninformed or the half-educated public. Musil, with his belief that constantly changing constellations (concepts, customs, political, social and economic criteria, moral and aesthetic values, etc...) alter the value of each element, shrank as much from the Austrian reactionary and proto-fascist tendencies of his day as he feared and abhorred the mystifications of aesthetes and backward-looking scholars in the humanities: the poetic elitism of the George-Circle, the ritual celebration of Heidegger's etymologies and digging up of ontological relations hidden in the structure of words, and also the Freudian archeology of culture condensed in the popular (and soon journalistic) notions of the Unconscious, the sexual trauma or the Oedipus complex.

\section{Bibliography and Abbreviations}

Amann, Klaus. Robert Musil - Literatur und Politik. Mit einer Neuedition ausgewählter politischer Schriften aus dem nachlass. Rowohlt: Reinbek bei Hamburg 2007.

. Literature and Politics. In: PAYNE, P. et. al. (Eds.). A Companion to the Works of Robert Musil. Rochester: Camden House 2007. p. 53-86

BARNOUw, Dagmar. Skepticism as a Literary Mode: David Hume and Robert Musil. In: MLN, Vol. 93, No. 5, Comparative Literature (Dec., 1978), p. 852-870

BAur, Uwe/ Goldschnigg, Dietmar (Hg.). Vom "Törless" zum "Mann ohne Eigenschaften". München: Fink 1973.

BonaCCHI, Silvia. Die Gestalt der Dichtung. Der Einfluss der Gestalttheorie auf das Werk Robert Musils. Bern: Peter Lang 1998. 
Rosenfield, K. H - Musil's Idea of Poetic Mastership

CoRngold, Stanley. Patterns of Justification in Young Törless. In: FeHn, A./ HoESTEREY, I./ TAtAR, M. (Eds.). Neverending Stories. Toward a Critical Narratology. Princeton N.J.: Princeton University Press 1992. p. 138-49.

FRIER, Wolfgang. Die Sprache der Emotionalität in den "Verwirrungen des Zöglings Törless". Bonn: Bouvier 1976.

HENNINGER, Peter. Die Wende in Robert Musil's Schaffen: 1920-1930 oder die Erfindung der Formel. In: BROKOPH-MAUCH, G. (Hg.). Robert Musil, Essayismus und Ironie. Tübingen: Franke 1992. p. 91-104.

HowALD, Stefan. Ästhetizismus und ästhetische Ideologiekritik. München: Fink 1984.

KISCH, Egon Erwin. Der Rasende Reporter (The raving Reporter). Berlin: Aufbau 2001.

KNÜPFERMANN, Volker. Die Gefährdung des Narziss oder: Zur Begründung und Problematik der Form in Thomas Manns Der Tod in Venedig und Robert Musils Die Verwirrungen des Zöglings Törless. In: Jost, R./ SchmidT-BergmanN, H. (Hg.). Dialog mit der Moderne. Frankfurt am Main: Athenäum 1986. p. 84-95.

LuSERKE-JAQUi, Matthias. Die Verwirrungen des Zöglings Törless: Adolescent Sexuality, the Authoritarian Mindset and the Limits of Language. In: PAYNE, P. et. al. (Eds.). A Companion to the Works of Robert Musil. Rochester: Camden House 2007. p. 151-174.

LUSERKE-JAQUI, Matthias. Robert Musil. Stuttgart: Metzler 1995.

Magnou, Jacqueline. De Törless à Noces ou Le vertige du moi. Peter Lang: Berlin,Vienna 1995.

MACH, Ernst. Die Analyse der Empfindungen. Jena: Fischer, 1902.

MATtENKLOTT, Gert. Der subjective Faktor in Musil's Törless. Mit einer Vorbemerkung über die Historizität der sinnlichen Wahrnehmung. In: Neue Hefte für Philosophie 4 (1973), 47-73.

MCBRIDE, Patrizia. The Void of Ethics. Robert Musil and the Experience of Modernity. Evanston: Northwestern UP 2006.

Mulot, Sybille. Der Junge Musil. Seine Beziehung zu Literatur und Kunst der Jahrhundertwende. Stuttgart: Metzler 1977.

MusIL, Robert. Gesammelte Werke in neun Bänden. Hg. Adolf Frise. Reinbek bei Hamburg: Rowohlt 1978.

MusiL, Robert. Briefe 1901-1942, 2 vols., Hg. Adolf Frisé. Reinbek bei Hamburg: Rowohlt 1981.

MuSIL, Robert. Sämtliche Erzählungen. Reinbek bei Hamburg: Rowohlt 1968.

MusIL, Robert. Kleine Prosa und Schriften. Reinbek bei Hamburg: Rowohlt 1978. (P)

MusIL, Robert. Tagebücher, 2 vols. Hg. Adolf Frise. Reinbek bei Hamburg: Rowohlt 1976 (TB I and TB II).

MusIL, Robert. Der Mann ohne Eigenschaften. Reinbek bei Hamburg: Rowohlt 1976. (MoE).

MUSIL, Robert. Pour une evaluation des doctrines de Mach. Paris: PUF 1980.

MusIL, Robert. Precision and Soul. Essays and Addresses. [Burton Pike and David S. Luft, eds. and transl.]. University of Chicago Press 1990. (PS) 
Rosenfield, K. H - Musil's Idea of Poetic Mastership

MusIL, Robert. The Confusions of Young Törless. [transl. Shaun Whiteside]. New York: Penguin 2001.

MusIL, Robert. The Man Without Qualities. [transl. Sophie Wilkins]. New York: Vintage 1995. (MwQ)

NEYMEYR, Barbara. Musil's skeptischer Fortschrittsoptimismus. Zur Ambivalenz der Gesellschaftskritik in seinen Essays. In: Zeitschrift für deutsche Philologie 115 (1996), 576-608.

NeYMEYR, Barbara. Utopie und Experiment. Zur Konzeption des Essays bei Musil und Adorno. In: Euphorion 94 (2000), 79-113.

NÜBEL, Birgit. Robert Musil. Essayismus als Selbstreflexion. New York, Berlin: De Gruyter 2006.

Payne, Philip/ Bartram, Graham/ Tikhanov, Galin (eds.). A Companion to the Works of Robert Musil. New York: Camden House 2007.

POTT, Hans-Georg. Robert Musil. München: Fink 1984.

REIS, Gilbert. Musil's Frage nach der Wirklichkeit. Königstein: Taunus, Hain 1983.

RogowsKI, Christian. Distinguished Outsider: Robert Musil and his Critics. New York|: Camden House 1994.

SCHRÖDER-WERLE, Renate. Erläuterungen und Dokumente. Robert Musil. Die Verwirrungen des Zöglings Törless. Stuttgart: Reclam 2001.

THÖMIG, Jürgen C.. Zur Rezeption von Musil- und Goethe-Texten. Historizität der ästhetischen Vermittlung von sinnlicher erkenntnis und Gefühlserlebnissen. München: Fink 1974.

THIHER, Allen. Understanding Robert Musil. Columbia: University of South Carolina Press 2009.

TURner, David. The Evasions of the Aesthete Törless. In: Forum for Modern Language Studies, vol. 10. No. 1 Jan. 1974, 19-44.

Ventureldi, Aldo. Robert Musil und das Projekt der Moderne. Bern: Peter Lang 1988.

Recebido em 30/03/2012

Aprovado em 28/05/2012 